\title{
William the Conqueror and Wessex
}

\author{
David Bates
}

This article is written in honour of a scholar whose many distinguished contributions include a history of Wessex that is the indispensable foundation for this analysis of how William the Conqueror (1066-87) shaped his Wessex inheritance. ${ }^{1}$ While adopting the standard definition of Wessex as consisting of the six historic counties of Devon, Dorset, Somerset, Wiltshire, Berkshire, and Hampshire, I only occasionally refer to Devon, since, although the Domesday record of that shire does contain typically 'Wessex' features, as far as we know William did not visit it after early 1068 when he besieged Exeter and then marched his army into Cornwall, before returning to Winchester to celebrate Easter. ${ }^{2}$ The article is also intended as a contribution to how different regions of England experienced the so-called Norman Conquest. ${ }^{3}$

Wessex's place in the English monarchy's history was entertainingly illuminated by the late James Campbell's comment that Wessex, the Thames Valley, and western Mercia largely remained the residential and governmental centre of the English kings and queens from the 1oth century until the time of Queen Victoria. ${ }^{4}$ This continuum was, however, one with many fluctuations both before and after 1066. From Æthelred the Unready's time (978-1016), kings had tended to concentrate their attention on the eastern Wessex shires, with Edward the Confessor's itinerary even suggesting a move away from Wessex and a preference for Westminster and Gloucester over Winchester. ${ }^{5}$ On the other hand, Winchester had been especially favoured by the Danish kings Cnut (1016-35) and Harthacnut (1040-42), both of whom were buried in the

1 Barbara Yorke, Wessex in the Early Middle Ages (London, 1995). I am grateful to Bob Higham and Ryan Lavelle for their comments on an earlier version of this article and to Sophie Rixon for her assistance during its preparation.

2 For the definition, Yorke, Wessex, p.r. For Devon, Robert Higham, Making Anglo-Saxon Devon: Emergence of a Shire (Exeter, 2008), pp. 150-52, 167-91, and 226-27.

3 For an important recent essay, Aleksandra McClain, "Rewriting the Narrative: Regional Dimensions of the Norman Conquest," in The Archaeology of the Eleventh Century: Continuities and Transformations, ed. Dawn M. Hadley and Christopher Dyer (London and New York, 2017), pp. 203-28.

4 James Campbell, "The United Kingdom of England: The Anglo-Saxon Achievement," in his The Anglo-Saxon State (London and New York, 200o), pp. 47-49.

5 Yorke, Wessex, pp. 144-48. 
cathedral. ${ }^{6}$ Wessex's centrality to the pre-1066 English kingdom was expressed in many other ways, with Winchester arguably having something of the character of a capital city and, because of the presence of the royal treasury, being an administrative centre for the kingdom. The site of three bishoprics and a high proportion of England's richest monasteries, both male and female, Wessex's religious institutions were also deeply embedded in the apparatus of royal rule. ${ }^{7}$ It had also been of central importance to the lives of England's two last pre-1066 queens, Emma, wife in turn of Æthelred the Unready and Cnut and mother of Harthacnut and Edward the Confessor (1042-66), and Edith, wife of Edward the Confessor. Edith was also the daughter of another major figure in Wessex's history, Godwin, earl of Wessex from Cnut's time until his death in 1053, and the sister of another one, his successor as earl, Harold, who became king of the English in 1066.

All this formed a multi-faceted basis for William the Conqueror's role in the history of Wessex that is arguably epitomised by the creation of the New Forest, by Winchester's central place in the making of Domesday Book, and by the construction of the huge new cathedral that began at Winchester in $1079 .{ }^{8}$ All in varying ways draw attention to the grandeur, symbolism, and changes at the heart of the history of William the Conqueror and Wessex. The massive size of Winchester cathedral, one of the largest churches in Christendom in some ways constructed as a deliberate imitation of St Peter's in Rome and of the cathedral church of Speyer built for the Emperor Conrad II (1024-39), can serve as an illustration. ${ }^{9}$

6 See recently, Martin Biddle and Birthe Kjølbye-Biddle, "Danish Royal Burials in Winchester: Cnut and His Family," in Danes in Wessex: The Scandinavian Impact on Southern England, c.80o-c.110o, ed. Ryan Lavelle and Simon Roffey (Oxford, 2016), pp. 212-49; Timothy Bolton, Cnut the Great (New Haven, and London, 2017), pp. 113-20, and 179-84.

7 For a central aspect of this subject, Barbara Yorke, Nunneries and the Anglo-Saxon Royal Houses (London and New York, 2003). See also Sarah Foot, Veiled Women, 1: The Disappearance of Nuns from Anglo-Saxon England (Aldershot, 2000), pp. 162-65.

8 Central to all modern understanding of Winchester is Martin Biddle, ed., Winchester in the Early Middle Ages: an Edition and Discussion of the Winton Domesday, Winchester Studies 1 (Oxford, 1976). For context, Sally Harvey, Domesday: Book of Judgement (Oxford, 2014), pp. 7-19; Judith A. Green, Forging the Kingdom: Power in English Society, 973-1189 (Cambridge, 2017), pp. 187-89.

9 Martin Biddle, "Seasonal Festivals and Residence: Winchester, Westminster and Gloucester in the Tenth to Twelfth Centuries," ANs 8 (1986), 51-72, at pp. 6o-63; Eric Fernie, The Architecture of Norman England, (Oxford, 2000), pp. 117-21, and "Three Romanesque Great Churches in Germany, France and England, and the Discipline of Architectural History," Architectural History 54 (2011), 1-22, at pp. 11-17. 


\section{The Installation of the New Regime}

According to the Carmen de Hastingae Proelio, the only source for the event, Winchester submitted to William during his army's march around the south of London after the Battle of Hastings, saying that the decision to do so was taken jointly by Queen Edith and the citizens. ${ }^{10}$ The indigenous population of Wessex was thereafter seemingly little involved in rebellions against the new regime, with, after Exeter's defiance in late 1067-68, the only two known uprisings taking place in all probability either in the summer or the early autumn of 1069, albeit with one possibly dating from 1071. According to Orderic Vitalis, probably at this point reworking or reproducing the lost later sections of the Gesta Guillelmi of William of Poitiers, one revolt involved men from Dorset and Somerset, who he described as West Saxons (Saxones orientales), and was defeated by Bishop Geoffrey of Coutances, who was one of William's closest associates and was in the process of becoming a major landholder in the western Wessex shires. Geoffrey is said to have used troops raised from Winchester, Salisbury, and London. ${ }^{11}$ Another revolt involved tenants of the abbey of Abingdon who joined in revolts whose nature and date are not specified in the abbey's Historia. ${ }^{12}$ There were also uprisings in Devon and Cornwall in 1069, probably associated with the failed attempts by King Harold's sons to establish a base to rally support. These were defeated by Earl William fitz Osbern and the Breton Earl Brian in alliance with the citizens of Exeter. ${ }^{13}$

Winchester, Salisbury and Exeter's support to the suppression of rebellion presumably indicates a significant readiness to work with the new regime. However, the dynamics of change immediately after 1066, which are the background to this article but not its subject, must surely have been more complex than they superficially appear to have been. ${ }^{14}$ The many individuals and

10 The Carmen de Hastingae Proelio of Guy Bishop of Amiens, ed. and trans. Frank Barlow (Oxford, 1999), pp. 36-39.

11 OV, 2:228-29.

12 Historia Ecclesie Abbendonensis: The History of the Church of Abingdon, 2.223, ed. and trans. John Hudson, 2 vols (Oxford, 2002-07), 1:226-7; David Bates, "Guillaume le Conquerant et les abbés anglais," in Sur les pas de Lanfranc, du Bec à Caen: recueil d'études en hommage à Véronique Gazeau, ed. Pierre Bauduin et al. (Caen, 2018), pp. 335-42.

13 OV, 2:228-29; Robert Higham, "William the Conqueror's Siege of Exeter in 1068," Transactions of the Devonshire Association 145 (2013), 93-132, at pp. 122-23.

14 Above all for now, Ann Williams, The English and the Norman Conquest (Woodbridge, 1995), pp. 78-80, 96-97, and 98-125; Ryan Lavelle, Royal Estates in Anglo-Saxon Wessex: Land, Politics and Family Strategies, BAR Brit. Ser. 439 (Oxford, 2007), pp. 102-16. The PASE database, <www.pase.ac.uk>, will allow the theme to be explored further. For arguments analogous to mine, Elisabeth van Houts, "The Memory of 1066 in Written and Oral 
communities across Wessex who had been closely associated with Godwin and Harold are unlikely to have submitted passively, at least not in their minds; a huge number of them must have known those who had died at Hastings and elsewhere or whose lands had subsequently been confiscated. The probable undercurrents of turbulence and discontent may suggest that some of the rebels of 1069 were followers of Mærleswein, a man who, while holding lands in many shires, has recently been identified as a royal agent originally based in Wessex, and who was among the group that unleashed the great revolt in northern England earlier in 1068. ${ }^{15}$ Arguably Mærleswein and other rebels must have waited until a revolt developed that had a reasonable prospect of success. Continuing resentment within Wessex is surely also demonstrated by the way in which Queen Edith's one surviving post-1066 charter, which dates from 1072 and was written in Old English, described William's Queen Matilda as his "bedfellow" (Mathyld his gebedde). ${ }^{16}$ The predominant narrative is arguably ultimately one of pragmatic submission in the face of overwhelming power.

William installed William fitz Osbern at Winchester early in 1067 before leaving England for Normandy, with William of Poitiers identifying the city as being a suitable place from which to govern the kingdom. He also described the citizens as untrustworthy. ${ }^{17}$ Orderic added to this that fitz Osbern also received the Isle of Wight. ${ }^{18}$ The evidence for William fitz Osbern's activities in Wessex and across much of southern and western England before his death in early 1071 can be used to help chart the chronology of change. ${ }^{19}$ Hence if, as has recently been argued, the creation of the so-called New Forest was one of the steps taken to protect the coast, an extension towards the sea of an existing foresta regis to support William fitz Osbern, then it can be seen as part of an apparatus created to defend against the raiding and invasions that had been a feature of Wessex's recent history and which are evidenced by Domesday's

Traditions," ANS 19 (1997), 167-79, at p.179 ("it is not enough to study the history of the Conquest purely in terms of questions about the continuity of Anglo-Saxon customs").

15 For this suggestion, C.P. Lewis, "Danish Landowners in Wessex in 1066," in Danes in Wessex, ed. Lavelle and Roffey, pp. 172-211, at pp. 183-84.

16 F.H. Dickinson, "The Sale of Combe," Somerset Archaeological and Natural History Society Proceedings 22 (1876), 106-13, at p. 107; Pauline Stafford, Queen Emma and Queen Edith (Oxford, 1997), p. 276. For this theme, David Bates, William the Conqueror (New Haven and London, 2016), pp. 262-63.

17 WP, II.35, pp. 164-65.

18 OV, 2:260-61.

19 C.P. Lewis, "William fitz Osbern, earl (d.1071)," ODNB <https://doi.org/10.1093/ref:odnb /9620> (accessed 29 Sept. 2017); Bates, William the Conqueror, pp. 299-300 and 342-43. 
references to damage caused at Fareham (Hants), by raids from the sea and further west in Devon, and to the presence of housecarls in the towns close to the Dorset coast. ${ }^{20}$ Although in some respects problematic, Domesday's references to the destruction of houses after 1066 in Dorset's towns also fit this pattern. Whether or not this involved the construction of castles, it is certain that the burhs of pre-1066 Wessex were continuing to be used as defensive centres. ${ }^{21}$ This early phase was also a time when William sought to recruit allies. His restoration of an estate to Bishop Giso of Wells in 1068 which, as the diploma in all probability drafted for Giso tells us, had been taken from the bishopric by King Harold, "inflamed by greed" (cupiditate inflammatus), was manifestly aimed to recruit support in the western Wessex shires. ${ }^{22}$

There are clear signs of deliberate efforts to articulate the continuum that was at the heart of William's claim to be the legitimate king of the English. He is known to have spent Easter at Winchester in 1068, 1069, and 1070, the first of the Easter crown-wearings there that were to be a feature of his rule. Although the 1068 assembly, which took place immediately after William's return from campaigning in Devon and Cornwall, is directly known only from a brief statement in the ' $\mathrm{D}$ ' version of the Anglo-Saxon Chronicle, charters in all likelihood associated with it indicate the continuation in office in Wessex of English officials alongside the presence of the new foreign elite. ${ }^{23}$ Charters dated to the 1069 assembly also show that many members of the surviving English and the new Norman/French elites were present. At the 1070 gathering papal legates performed a type of second coronation for William and confirmed the deposition of Archbishop Stigand of Canterbury, who was also bishop of Winchester, and of other bishops and abbots.

Wessex and Winchester were therefore at the heart of William's English rule from the start. Following the pattern in every other major urban centre, a castle was erected within the walls involving considerable destruction and the takeover of an area of approximately 5.7 acres, probably a comment on William of

$20 \quad$ Karin Mew, "The Dynamics of Lordship and Landscape as revealed in a Domesday Study of the Nova Foresta," ANs 23 (2001), 155-66, at pp. 162-65; G DB, fols 40v, 75r; Yorke, Wessex, pp. 142-43; Higham, "William the Conqueror's Siege of Exeter," pp. 122-23.

$21 D B$, i, fol. 75r; Laurence Keen, "An Introduction to the Dorset Domesday," in The Dorset Domesday, Ann Williams and R.W.H. Erskine, Alecto Historical Editions (London, 1991), pp. 18-20.

22 Regesta Regum Anglo-Normannorum: The Acta of William I (1066-1087), ed. David Bates (Oxford, 1998), no. 286 (henceforth, Acta); Simon Keynes, "Giso, Bishop of Wells," ANs 19 (1997), 203-71, at pp. 242-43, $25^{8}$ (no.14). For William's cultivation of bishops, Bates, William the Conqueror, p.293.

23 ASC D 1067 (recte 1068); Acta, nos. 181, 286. On these charters, see Richard Sharpe, "The Earliest Norman Sheriffs," History 101 (2016), 485-94, at pp. 490-91, 492. 
Poitiers' belief that the citizens could not be trusted. ${ }^{24}$ Also, in c.1070, the enclosure of the royal palace was doubled in size by taking in the cemetery of one of the two great Winchester monasteries, the New Minster. ${ }^{25}$ During this period, William also compensated Edward the Confessor's religious foundation at Westminster with a generous exchange to enhance royal resources at Windsor; a narrative inserted into a 12th-century forged charter indicates that this was done so that William could hunt in the nearby forest. ${ }^{26}$ Windsor, described in the Vita Edwardi Regis as a royal town (regale municipium), also became a centre at which great assemblies were held, with the two of them held there in 1070 and 1072 dealing with major matters affecting the English Church. ${ }^{27}$ This emphasis on Berkshire and also, as we shall see, on the abbey of Abingdon, shows that William's regime was consciously maintaining the tradition of Berkshire's integration into Wessex that went back to the time of Alfred the Great. $^{28}$

\section{Crown-Wearings, Itinerary, and Infrastructure}

From 1072 until his death in 1087, on as precise an estimate is possible, although William spent only between 23 and 24 per cent of his time in England, a visible presence in Wessex and at Winchester remained central to his English rule. He is known to have spent Easter at Winchester in 1072 and 1086, is likely to done so in 1071 and 1076 , and possibly did so in 1081. In short, whenever he was in England, he aimed to be at Winchester for Easter, a statement that might at first sight appear surprising given the years when he was demonstrably not there. It does, however, become utterly convincing when we realise that he could not possibly have been there in 1073, 1075, 1077, 1078, 1079, 1080, 1082, 1083,1085 , and 1087, and that visits to England in 1074 and 1084 are extremely unlikely. As is well known, all this is part of the pattern whereby William wore his crown at Winchester at Easter, at Westminster at Whitsun, and at Gloucester at Christmas whenever he was in England that is famously described in the Anglo-Saxon Chronicle. ${ }^{29}$ That this was not his invariable practice, as shown by

\footnotetext{
24 Biddle, ed., Winchester, pp. 302-03.

25 Biddle, ed., Winchester, pp. 292-305; Acta, no. 344.

26 Acta, nos. 290, 299; Barbara Harvey, Westminster Abbey and its Estates in the Middle Ages (Oxford, 1977), pp. 27-28; Emma Mason, Westminster Abbey and its People, c.1050-c.1216 (Woodbridge, 1996), p. 16.

$27 \quad V Æ d R$, 2nd ed., pp. 100-01.

28 Yorke, Wessex, pp. 95-96.

$29 \quad$ ASC E 1086 (recte 1087).
} 
his having been at Winchester for Whitsun in 1081 and at Windsor at Whitsun in 1070 and 1072, makes no difference to the basic point about an itinerary that symbolically replicated the English past. While Windsor has some of the characteristics of the other places, it was probably not thought a crown-wearing centre because it lacked the religious institutions that were present at the other three. ${ }^{30}$

William's two stays in England in 1080-81 and 1085-86 involved him and his entourage moving eastwards and westwards across Wessex. In 1080-81, he travelled from Gloucester at Christmas 1080 to London by February 1081, then to Winchester by late May, and then to St David's in west Wales, before crossing to Normandy in the autumn, presumably from either Portsmouth or Southampton. ${ }^{31}$ In $1085^{-86}$, after spending Christmas 1085 at Gloucester, he seems to have moved into Wessex and stayed there until his departure for Normandy in the autumn. The signa of the charters and the records of business also show that many of the great men of the English kingdom were in his company during these periods. The crown-wearings also sometimes coincided with councils attended by the bishops and abbots of the English Church. The volume of business and the logistics associated with bringing the returns to the Domesday survey to William in 1086 and the taking of the Salisbury Oath on 1 August must have been huge.

Charters and narratives also demonstrate William's presence within Wessex at Salisbury/Old Sarum in February 1081 and on 1 August 1086, at North or South Petherton (Somerset) in all probability in the spring of 1071, on the bishop of Winchester's estate of Downton (Wiltshire) in 1082, on the Isle of Wight for the arrest of his brother Bishop Odo of Bayeux later in 1082 or early in 1083 , and at Lacock (Wiltshire) in $1086 .{ }^{32}$ The Abingdon Historia tells us that William was accustomed to go to the island of Andersey in the Thames to the south of Abingdon for rest cures that included blood-letting. ${ }^{33} \mathrm{~A}$ writ-charter attributed to William in the Historia indicates a journey a little beyond Wessex to Brill

3o Michael Hare, "Kings, Crowns, and Festivals: the Origins of Gloucester as a Royal Ceremonial Centre," Transactions of the Bristol and Gloucestershire Archaeological Society 115 (1997), 41-78, at pp. 48-57, and with Windsor discussed at pp. 54-55.

31 Bates, William the Conqueror, pp. 429-33.

32 Acta, nos. 154, 268; ASC E 1086; Vita Wlstani, in William of Malmesbury: Saints'Lives, 2.2, ed. and trans. Michael Winterbottom and Rodney M. Thomson (Oxford, 2002), pp. 62-65. For Odo's arrest, Bates, William the Conqueror, pp. 443-44. For the identification of Lacock, see the Institute for Name Studies website, Key to English Place-Names $<$ http://kepn.not tingham.ac.uk/map/place/Wiltshire/Lacock $>$.

Historia Ecclesie Abbendonensis, 2:72-73. 
(Bucks.). ${ }^{34}$ Provision for leisure as well as for the formal rule was central to William's relationship with Wessex. William's long absences in France notwithstanding, all this would have required at least the retention of the infrastructure that had supported the itineraries within Wessex of the pre-1066 kings, all the more so because, according to William of Malmesbury, writing in the early 12th century, William's crown-wearings were especially magnificent. ${ }^{35}$

Although the Domesday evidence presents some problems because Hampshire and Berkshire were included in Circuit I of the survey and Dorset, Wiltshire, and Somerset in Circuit II, there is no doubt that the system that had sustained royal itineraries before 1066 supported William's as well, with there being clear signs that it was significantly expanded. The 'farm of one night' (firma unius noctis), or 'the farm of one day' (firma unius diei) in Hampshire, was rendered either in kind or cash by the majority of the royal lands in Hampshire, Dorset, Wiltshire, and Somerset recorded in Domesday as held by Edward the Confessor and subsequently transferred to William. ${ }^{36}$ Exemption from paying geld continues on many of these estates, with the Domesday accounts for Dorset, Wiltshire and Somerset being close to formulaically repetitious in stating that the estates did not pay geld and had never done so. ${ }^{37}$ The same looks to be true for Hampshire and, with some variations, for Berkshire. ${ }^{38}$ The first entry in the terra regis for Wiltshire (Calne) is actually set out in a way that explains the situation ("it has never paid geld; hence it is not known how many hides are there" [nunquam geldauit, ideo nescitur quot hidae sint ibi]), with the entries thereafter repeating an identical phrase in a way that indicates that the arrangements dated back to beyond the memories of the Domesday jurors and the central administration responsible for collecting the tax. ${ }^{39}$ Its special character is also reflected by the way in which the Circuit II shires (Dorset, Wiltshire, and Somerset) categorise the terra regis separately as inherited royal demesne before subsequently describing the lands acquired from both

34 Acta, no. 6; Historia Ecclesie Abbendonensis, 2:2-5. The document's diplomatic suggests that it dates from William II's reign, but the Historia attributes it to William I.

35 WM, GRA, ch. 279, pp. 508-09.

36 For a recent discussion, Lavelle, Royal Estates in Anglo-Saxon Wessex, pp. 13-47. Also, Pauline Stafford, "The 'Farm of One Night' and the Organization of King Edward's Estates in Domesday," Economic History Review, 2nd ser. 33 (1980), 491-502, at pp. 492-93 and 499-501. GDB, fols $64 \mathrm{v}-65 \mathrm{v}, 75 \mathrm{rv}, 86 \mathrm{r}-87 \mathrm{r}$. Thus, for example, Nunquam geldauit, nec hidata fuit in the entry for Bedwyn (Wilts.), fol. $64 \mathrm{v}$.

38 GDB, fols $38 \mathrm{r}-39 v$, and $56 \mathrm{v}-57$ r; B.J. Golding, "An Introduction to the Hampshire Domesday," in The Hampshire Domesday, ed. Ann Williams and R.W.H. Erskine, Alecto Historical Editions (London, 1989), pp. 1-27, at pp. 20-21. GDB, fol. $64 \mathrm{v}$. 
Godwin's family and others and from the deceased Queen Matilda, with rubrications inserted in Dorset making this specific distinction. The purpose of the exemptions, both before and after 1066, would have been to protect the estates from the unpredictable consequences of a tax levied at varying and sometimes oppressive rates. The arrangements were unique to the Wessex shires. ${ }^{40}$

There is a pattern on some of the lands once held by Earl Godwin's family, most notably by his sons Harold and Tostig, by his wife Gytha, and — presumably after 1075-by Queen Edith, incorporated into the royal lands for the assessment to geld often to be either reduced or abolished, even though all these estates had previously been assessed to the geld and many continued to be. Long-standing arrangements that were uniquely favourable to the king were therefore being extended to acquisitions. Many of the incorporated estates were recorded as paying renders, often at a level above the estate's recorded value and at a significantly higher level than before $1066 .{ }^{41}$ That this process could be pushed too hard is graphically illustrated by the record of East Meon (Hants), a very large estate that Stigand, archbishop of Canterbury and bishop of Winchester, was said to be holding on behalf of the Old Minster, and which was valued at $£ 6 o$ and, after being included in the king's lands, was at farm at $£ 100$, but, so the entry says, "it cannot bear it." ${ }^{\text {2 }}$

The places that William is known to have visited had a long association with kings and were also usually in close proximity to forest where he and his nobles could hunt. North and South Petherton were large royal estates inherited from Edward the Confessor that both rendered the farm of one night and had the standard exemption from paying any geld. Both were relatively close to the Quantock Forest and the Neroche Forest. ${ }^{43}$ The Thames island of Andersey had been a royal residence in the times of Kings Offa of Mercia (757-96) and Æthelstan (924-39). In the 11th century a minster was being built there by the priest Blæcmann, a close associate of Earl Godwin. ${ }^{44}$ Brill, which is

40 See, for example, R.S. Hoyt, The Royal Demesne in English Constitutional History, 1066-1272 (Ithaca, NY, 1950), pp. 19-25.

41 See, J.H. Round, "Introduction to the Hampshire Domesday," in $v c H$ Hants, 1: 399-447, at pp. 413-15; Golding, "An Introduction to the Hampshire Domesday," p. 21.

42 "Sed non potest pati." GDB, fol. 38r.

43 GDB, fol. 86r; James Bond, "Forests, Chases, Warrens and Parks in Medieval Wessex," in The Medieval Landscape of Wessex, ed. Michael Aston and Carenza Lewis (Oxford, 1994), pp. 115-58, at pp. 120, 121, 131, and 134 .

44 For the narratives of Andersey's history, Historia Ecclesie Abbendonensis, 1:lvii, cviii-cix, 208-09, and 372-73; 2:cviii-cix, and 72-73; "De Abbatibus Abbendonie," in Chronicon Monasterii de Abingdon, ed. J. Stevenson, RS 2, 2 vols (London, 1858), 2:273, 277; Charters of Abingdon Abbey, ed. Susan E. Kelly, Anglo-Saxon Charters 7 and 8, 2 parts (Oxford, 2000-1), 2:clx-clxi, ccii-cciii. 
approximately 14 miles to the north of Andersey, was the site of a royal residence built by Edward the Confessor whose grandeur merited it being described as a palatium; it was the base for hunting in nearby Bernwood Forest. ${ }^{45}$ One place that William cannot be shown to have visited, however, is Clarendon, with the famous Evesham knight-service writ that says that William mustered troops there now having been shown to be a 12th-century forgery. ${ }^{46}$ Even if Clarendon only became one of the great royal residences from Henry I's reign onwards, the tradition recorded in the forged writ may nonetheless be significant; there is clear evidence that Clarendon had been a park frequented by kings before 1066 and Edward the Confessor's presence in 1065 at nearby Britford indicating that it was so used at the time of the Conquest. ${ }^{47}$

Most of the forest and hunting officials recorded in Domesday Book appear in Hampshire, Wiltshire, and Dorset, with some of them having been tenants there in the time of Edward the Confessor. ${ }^{48}$ There are mentions of 'forest' in most of the Wessex shires, with it being possible to deduce that they refer to forests to which names can be assigned. ${ }^{49}$ The presence of Waleran the huntsman as a substantial tenant-in-chief in Dorset, Hampshire, and Wiltshire is just one indication of the existence of an associated hierarchical managerial organisation. ${ }^{50}$ It is, however, only in the cases of the New Forest and Windsor that significant change during William's reign can be identified. Whatever is made of the extensive literature on the Nova Foresta and the levels of continuity involved in its creation and in the history of parks, woodlands, and enclosed spaces, the scale of spatial and territorial change that took place produced such shock for historians writing in both Normandy and England in the 12th century that it must have seemed dramatic. ${ }^{51}$ In the case of Windsor, in

$45 V E d R$, 2nd ed., pp. 98-99; G D B, fol. 143v; I.M.W. Harvey, "Bernwood in the Middle Ages," in Bernwood: The Life and Afterlife of a Forest, Harris Papers 2 (Preston, 1997), pp. 1-2.

46 Regesta, no. 131; Nicholas Vincent, "The Use and Abuse of Anglo-Saxon Charters by the Kings of England, 1100-1300," in The Long Twelfth-Century View of the Anglo-Saxon Past, ed. Martin Brett and David A. Woodman (Aldershot, 2015), pp. 191-228, at pp. 223-25.

$V Æ d R$, 2nd ed., pp. 78-79; Tom Beaumont James and Christopher Gerard, Clarendon: Landscape of Kings (Macclesfield, 2007), pp. 43-47.

48 Graham Jones, "A 'Common of Hunting'? Forests, Lordship and Community before and after the Conquest," in Forests and Chases of England and Wales c.10oo-150o, ed. John Langton and Graham Jones (Oxford, 2010), pp. 36-67, at p. 67.

49 Thus, for example, F.R. Thorn, "Hundreds and Wapentakes," in The Wiltshire Domesday, ed. Ann Williams and R.W.H. Erskine, Alecto Historical Editions (London, 1989), pp. 3145 , at p.37.

$5^{\circ} \quad$ GDB, fols. 48rv, 72r, 82r.

$51 \quad$ Mew, "The Dynamics of Lordship," pp. 157-63. In general, Alban Gautier, "Game Parks in Sussex and the Godwinessons," ANS 29, (2007), 51-64; Judith A. Green, "Forest Laws in England and Normandy in the Twelfth Century," Historical Research, 86, (2013), 416-31. 
addition to the exchange with the abbey of Westminster mentioned above, the Abingdon Historia records that four hides had been removed from Winkfield (Berks.) by William's judgement to expand the forest at Windsor. ${ }^{52}$ The minutiae of this remarkable infrastructure are wonderfully illuminated by Domesday's mention of Godric's wife who was holding land in East and West Hendred because she was caring for the king's dogs. ${ }^{53}$

\section{William's Family and Wessex}

The evidence for William's family's presence in Wessex demonstrates a deliberate policy of maintaining tradition. His second son Richard's death in a hunting accident in the New Forest in $c .1070$ and his burial in Winchester cathedral are facets of this, an indication both of presence there during his life-time and of a status that merited a place alongside the numerous kings and queens already entombed there. ${ }^{54}$ The reference in Domesday Book to Geoffrey the chamberlain holding Hatch Warren in Hampshire for the service he had performed for the king's daughter Matilda indicates her presence in Wessex, suggesting that she was being educated at one of the Wessex nunneries, with Wilton, where Queen Edith had been educated, or the Nunnaminster in Winchester, being the most likely possibilities. ${ }^{55}$ Although the names and sequence of William's and Matilda's daughters present problems, Matilda's existence is certain because the mortuary roll of Matilda, the first abbess of La Trinité of Caen, who died in 1113, asked for prayers for her soul and listed her with others of William's deceased daughters who had all been lay women. ${ }^{56}$ These being the only two known references to her, it is likely that she died young and that she was fulfilling the tradition of a female royal presence in Wessex. ${ }^{57}$ While perhaps excessively speculative, it is impossible not to suggest that she would have met with Edith, the sister of Edgar the Ætheling and future

52 Historia Ecclesie Abbendonensis, 2.6, 2, pp. 8-9; GDB, fol. 59r; Jane Roberts, Royal Landscape: The Gardens and Parks of Windsor (New Haven and London, 1997), pp. 7-10.

53 GDB, fol.57v. See above, Ryan Lavelle, "Places I'll Remember? Reflections on Alfred, Asser and the Power of Memory in the West Saxon Landscape," above, at p. 333.

54 OV, 3:114-15; WM, GRA, ch. 275, 1:502-05; Biddle and Kjølbye-Biddle, "Danish Royal Burials," pp. 224-25, and 227.

55 GDB, fol. 49r.

56 Recueil des rouleaux des morts (VIII ${ }^{e}-$ vers 1536 ), ed. Jean Dufour, 4 vols (Paris, 2005-8), 1: p. 398 (no. 114). Léopold Delisle's and Jean Dufour's mistaken identification of Matilda, the first abbess of La Trinité, as a daughter of William and Matilda was corrected by Frank Barlow, William Rufus (London, 1983), p. 442; cf, Yorke, Nunneries, p. 92.

The extensive literature is summarised in Yorke, Nunneries, pp. 89-92. 
wife of Matilda's brother King Henry I, and Gunnhild, King Harold's daughter and future wife of Count Alan Rufus, one of the greatest of the cross-Channel elite, both of whom were being educated in Wessex nunneries.

A certain presence in Wessex is the future King Henry I, William's and Matilda's youngest child, in all probability educated in Wessex with Bishop Osmund of Salisbury a likely tutor. Henry resided for a time at the abbey of Abingdon where he is known to have been at Easter in $1084 .{ }^{58}$ Where his father intended this to take him is of course unknown and is undiscoverable because of the conflicts that followed William's death. There is, however, significant evidence that Henry's links with the region around Abingdon formed during his adolescence were sufficiently strong to have a powerful influence on his adult life. ${ }^{59}$ This attachment may well explain why he developed Woodstock (Oxon.) and Clarendon as residences.

William's wife Matilda was prominent in Wessex up until her death in 1083. An extensive landholder in many south-western shires, she had held a large manor in Hampshire and was a major landholder in Devon and Dorset, where her estates merited the insertion of two rubrics into the Domesday text, the second of which drew attention to lands that had been administered on her behalf by the sheriff Hugh fitz Grip. ${ }^{60}$ She is recorded in Domesday as making grants to the Norman monasteries of Le Bec and La Trinité and Saint-Etienne of Caen and, in a charter, to have given a chasuble made in Winchester to La Trinité. ${ }^{61}$ There are records of grants made by her to individuals, some of whom were certainly of English birth, of the restoration of a small estate in Hampshire to an Englishman, and of her doing justice. ${ }^{62}$ The Geld Rolls preserved in Exon Domesday mention that she had granted exemption from geld to "a certain widow" (quidam uidua) for Matilda's deceased son Richard's soul. ${ }^{63}$

While in no way being equivalent in scale to that of Queens Emma and Edith, Matilda's recorded activity in Wessex is notable, especially as she spent even more time in Normandy than her husband. Her consistent presence

$5^{8}$ Historia Ecclesie Abbendonensis, 2:16-19; C. Warren Hollister, edited and completed by A. Clark Frost, Henry I (London and New Haven, 2001), pp. 35-37; Judith A. Green, Henry I, King of England Duke of Normandy (Cambridge, 2006), pp. 22-23.

59 David Crouch, "Robert of Gloucester's Mother and Sexual Politics in Norman Oxfordshire," Historical Research 72 (1999), 323-33, at pp. 327-30.

6o GDB, fols $38 \mathrm{r}, 75 \mathrm{v}$ (Has subter scriptas terras tenuit Mathildis regina and Has octo infra scriptas terras tenuit Hugof. Grip de Regina), and 101rv. For Matilda's estates, Lavelle, Royal Estates in Anglo-Saxon Wessex, pp. 84-87.

$61 \quad$ GDB, fols $68 \mathrm{v}, 78 \mathrm{v}$; Acta, no. 63 .

62 GDB, fols $38 \mathrm{r}, 48 \mathrm{v}, 84 \mathrm{r}(\times 2)$.

63 "The Dorset Geld Rolls," ed. and trans. Ann Williams, in VCH Dorset, 3: 128. 
among the signa of William's English diplomas does show that she invariably crossed the Channel for the great occasions that took place in Wessex. We also know that she acted independently there during one period of several months in 1081-82 when William was in Normandy and when, among other things, she dispensed justice on his behalf at Windsor. ${ }^{64}$ Her role in persuading Bishop Osbern of Exeter to restore the church of Wedmore (Som.) to the Bishop Giso of Wells could be a deliberate continuation of Edith's favour to Giso. ${ }^{65}$ In February 1081, she granted Garsdon (Wilts.) to the abbey of Malmesbury, with the diploma's reference to her as William's legalis coniunx possibly being one of those coded jibes at the new regime indicative of continuing resentment. ${ }^{66}$ She also used the known royal itinerary in Wessex to demand gifts from the abbey of Abingdon, only to reject what was offered and extort much more valuable ones, namely a chasuble, an alb with a stole, and a Gospel book, all of which the monks regarded as being among their greatest treasures. ${ }^{67} \mathrm{Her}$ long absences in Normandy notwithstanding, it looks as if she was playing a role that conceptually and episodically sustained that of the most recent English queens. The concentration of many of her lands and activities in the western Wessex shires may well indicate responsibility for them was assigned to her, a suggestion that gathers strength from William's own focus having primarily been on the eastern shires.

Even though Richard and William Rufus, the two of William's sons who died in hunting accidents in the New Forest, were buried in Winchester cathedral, it is ultimately doubtful that William thought of it as becoming a royal mausoleum; in all likelihood, Saint-Etienne of Caen was always destined to be where he was going to be buried. Richard's burial at Winchester alongside the kings and queens Cnut, Harthacnut, Emma and Edmund Ironside, as well as Earl Beorn, nonetheless demonstrates William locating his family within the dynastic continuity that was central to his claim to legitimacy. ${ }^{68}$ His own burial must be seen as a manifestation of the contemporary trend to abandon burial

64 In general, David Bates, "The Representation of Queens and Queenship in Anglo-Norman Royal Charters," in Frankland: Essays in Honour of Dame Jinty Nelson, ed. Paul Fouracre and David Ganz (Manchester, 2008), pp. 285-303, at pp. 287-90. For 1081-82, Bates, William the Conqueror, pp. 433-35.

65 Acta, no. 289; Keynes, "Giso," pp. 227-39; Stafford, Queen Emma and Queen Edith, pp. 147-48.

66 Acta, no. 193.

67 Historia Ecclesie Abbendonensis, 1:224-5.

68 Biddle and Kjølbye-Biddle, "Danish Royal Burials," pp. 219-28, with the suggestion that William envisaged burial at Winchester at pp. 227-28; cf, Bates, William the Conqueror, pp. 169-70. 
in a mausoleum in favour of one in a personal monastic foundation, a change epitomised in England by Edward the Confessor's and Edith's burial at Westminster. ${ }^{69}$ Henry I's foundation of the abbey of Reading and his decision to be buried there, as well as being a response to a family tragedy, may well represent not just another expression of this trend, but also a personal continuation of his father's close relations with Cluny. His cultivation of Wessex and Windsor was perhaps founded in memories of childhood spent there. ${ }^{70}$

\section{Wessex and the Cross-Channel Empire}

The way in which Wessex's geographical location made it the English core of the new cross-Channel empire is evident in multiple ways. ${ }^{71}$ Although the ports at which William embarked and disembarked when he made his many Channel crossings are rarely named in the sources, the crossing from either Caen or Ouistreham or from the Seine valley into the Solent, with hunting in the New Forest en route, was the most convenient one for him to take. I have recently suggested that it was "the axis on which the cross-Channel empire turned."72 Domesday's account of Southampton mentions that sixty-five Frenchmen and thirty-one Englishmen have been settled there "after King William came to England" (Postquam rex W. uenit in Angliam hospitati in Hantone lxv francigene et xxxi angligene). When wives and families are taken into account, this is a significant increase in population. Those who possessed houses there include newcomers who were the great landholders in the shires of western England, namely, Bishop Geoffrey of Coutances, Count Robert of Mortain, and Ralph de Mortemer, all presumably using the property for themselves or their associates as residences at which to stay when they had crossed the Channel or were about to cross it. Also present among the holders of houses are the abbeys of Lyre and Cormeilles which were William fitz Osbern's two main monastic foundations, the count of Evreux, and Stephen the steersman. ${ }^{73}$ All four are indicative in different ways of the establishment of a new presence; the

69 Elizabeth M. Hallam, "Royal Burial and the Cult of Kingship in France and England, 106o1330," Journal of Medieval History, 8, (1982), 339-80, at pp. 367-77.

70 For Henry and Reading, Hollister, Henry I, pp. 282-87; Green, Henry I, pp. 170-72. Lavelle, "Places I'll Remember?" above, pp. 313-335, provides an exploration of childhood memory, albeit in a dfferent period.

71 For my usage of the word "empire," David Bates, The Normans and Empire (Oxford, 2013), pp. 8-11.

72 Bates, William the Conqueror, p. 500.

73 GDB, fol. $5^{2 r}$. 
abbeys because they transported William fitz Osbern's image as a religious patron into England; Count William of Evreux, while he held land in England only in Berkshire and Oxfordshire in addition to the house in Southampton, so that he could attend court at Winchester, Windsor, and elsewhere; and Stephen because he may well have been the man who steered William the Conqueror's ship when he crossed the Channel. ${ }^{74}$ This remarkable agglomeration, combining as it did practicality and a physical demonstration of presence, may well be what has been referred to as the 'castle town' that was "inserted alongside an existing street axis."75

Somerset excepted, where Bishop Geoffrey of Coutances and Count Robert of Mortain had massive landholdings, there is no dominant landholder recorded in Domesday Book in any of the other Wessex shires, apart from each one's sheriff. Instead there is a multiplicity of landholders who included the most powerful members of the cross-Channel elite, but with all of them usually holding only a small number of estates. Hampshire unsurprisingly supplies the most remarkable illustration of this phenomenon, since, presumably because of Winchester, every one of the well-known list of the so-called 'Class A' magnates appear, but with only Roger de Montgommery holding a sizeable estate. ${ }^{76}$ That this process is another one that started early in William's reign is indicated by William fitz Osbern's grant to Roger de Montgommery of the large estate of Chalton (Hants), presumably as a stopping-off point for Roger on his journeys to and from Normandy to his earldom on the Welsh border. ${ }^{77}$ The same phenomenon is present, albeit in reduced form and with some of the group holding larger estates, in Dorset and Wiltshire. ${ }^{78}$ Also significant must be the appearance in Dorset of Roger de Beaumont, a massively important member of the new regime and without doubt the most powerful Norman layman not to hold much land in England..$^{79}$ Surely what was involved for him was a presence in Wessex to enable court attendance, but which did not involve huge cross-Channel responsibilities. It is also likely that a puzzling feature of the Domesday evidence, the apparently excessive destruction of houses in the

74 GDB, fol. 52r. For Stephen, OV, 6:296-97.

75 Keith D. Lilley, "The Norman Conquest and its Influences on the Urban Landscape," in The Archaeology of the Eleventh Century, ed. Dyer and Hadley, pp. 41-63, at pp. 36-7.

76 GDB, fols 38r, 44v, 47r. For the "Class A" categorisation, C. Warren Hollister, "The Greater Domesday Tenants-in-Chief," in Domesday Studies: Papers Read at the Novocentenary Conference of the Royal Historical Society and the Institute of British Geographers, Winchester, 1986, ed. J.C. Holt (Woodbridge, 1987), pp. 219-48, at p. 242.

77 GDB, fol. $44 \mathrm{v}$.

78 GDB, fols 66r, 68v-69r, 71r, 77r, 78r-8or.

79 GDB, fol. 8or. 
Dorset towns and the variable evidence on the ground for the presence of castles was a reflection of these arrangements' success. The sheriff Hugh fitz Grip, who is regularly named as the culprit, may well have over-reacted to the needs of security. ${ }^{80}$

Another manifestation of the development of cross-Channel links that consolidated presences between Normandy and Wessex involved the grant before 1086 of lands and churches to almost all of the main monasteries of Normandy and to some French abbeys as well. Thus, the abbeys of Grestain, Jumièges, Lyre, Troarn, Saint-Wandrille, Saint-Etienne of Caen, La Trinité of Caen, Montivilliers, Marmoutier, Fontenay, Montebourg, Saint-Pierre of Préaux and SaintSéver all received lands in Wessex, as also did the canons of the cathedral churches of Lisieux and Coutances. ${ }^{81}$ Very notable too is the number of churches that had been transferred to Norman monasteries, with the abbeys of Cormeilles, Lyre, and Mont Saint-Michel holding churches in Hampshire, of which Lyre held a remarkable eight, seven of which were on the Isle of Wight, ${ }^{82}$ SaintWandrille two in Dorset, ${ }^{83}$ Jumièges, Saint-Wandrille, and Saint-Etienne of Caen one each and Mont Saint-Michel two in Wiltshire, ${ }^{84}$ Mont Saint-Michel one in Berkshire, ${ }^{85}$ and Saint-Etienne of Caen one in Somerset. ${ }^{86}$ One striking feature of this list is the number of grants of churches on royal lands, something that must be attributable to William himself. The relationship between the grants and the cross-Channel holdings of the topmost imperial elite, and the fact that almost all of the abbeys concerned had ready access to the sea in Normandy and therefore to the crossing to Wessex, must also be significant. William himself made it as financially easy as possible for the two Caen abbeys and the abbey of Grestain, where his mother was buried, to operate within this new world. ${ }^{87}$ This process of integrating religious institutions associated with

80 GDB, fol. 75r; Keen, "An Introduction to the Dorset Domesday," pp. 18-20.

81 Grestain, GDB, fol.43v (Hants), 68v (Wilts.); Jumièges, GDB, fol. 43v; Lyre, GDB, fol.38v, 39v, 52r (Hants); Troarn, GD B, fol. 44v (Hants); Saint-Wandrille, GD B, fol. 75 r (Dors.); SaintEtienne of Caen, GDB, fol.78v (Dors.) and fol. 91r (Som.); La Trinité of Caen (Dors.), GDB, fol. 79r (Dors.); Montivilliers, GDB, fol. $79 r$ (Dors.); Marmoutier, GDB, fol. 79r (Dors.); Fontenay, GDB, fol. 72v; Montebourg, GDB, fol. 73r (Wilts) and fol.9ir (Soms.); Saint-Pierre of Préaux, GD B, fol. 6or (Berks.); Saint-Séver, GDB, fol. 91v (Soms.). For the canons of Lisieux and Coutances, GDB, fols $65 \mathrm{v}$ (Wilts.) and $79 \mathrm{r}$ (Dors.).

82 GDB, fol. 49r (Cormeilles), and fols 39v, 52r, 52v (Lyre); fol.43r (Mont Saint-Michel).

83 GDB, fol. $78 \mathrm{v}$.

84 GDB, fol. 65 r.

85 GDB, fol. 57 r.

86 GDB, fol. gir.

87 Acta, no. 158 (quocumque deferantur uel ducantur tam in Anglica quam in Normannia, sicuti ecclesia sancti Stephani Cadomensis habet ubique sua dominie quieta). 
the new regime into the royal itinerary in Wessex also involved Battle Abbey receiving lands in Berkshire and a house in Windsor. ${ }^{88}$

\section{William and the Great Churches of Wessex}

On the basis of the evidence of 11th-century charters and Domesday Book, William's relationship with many of Wessex's religious institutions appears to have been supportive, without being generous. ${ }^{89}$ There are many instances starting from early in the reign of confirmations or restorations of property and he heard disputes between monasteries that were resolved according to English traditions. ${ }^{90}$ His grant of Hempage Wood (Hants) to support the construction of the new cathedral at Winchester later became the subject of an entertaining story. ${ }^{91} \mathrm{He}$ was to an extent supportive of English abbots staying in post, with, for example, Abbot Æthelnoth of Glastonbury remaining in office until his death in c.1082. Also, after Abbot Ælfwig, who may well have been a kinsman of King Harold, had been killed at the Battle of Hastings, the monks of New Minster were allowed to appoint an English monk named Wulfric in 1069; he was, however, deposed in $1072 .{ }^{92}$ William famously intervened in the making of Domesday Book to ensure that the services and customs due to the bishop of Winchester at Taunton were entered in the written record of the survey (in breuibus scriberet)..$^{93}$ His restoration of Laverstoke (Hants) to the Old Minster so that the monks would pray for Matilda's soul shows that he held the abbey in special esteem; in England only the abbey of Bury St Edmunds, with which he appears to have had a special relationship, was singled out as so uniquely important. ${ }^{94}$ On the other hand, there are few records of him making grants

88 GDB, fol. 59v; Regesta Regum Anglo-Normmanorum vol. 2, Regesta Regis Henrici Primi, 1100-1135, ed. Charles Johnson and H.A. Cronne (Oxford, 1956), no. 1807.

89 For a survey and a clear statement, Round, "Introduction to the Hampshire Domesday," pp. 416-21 ("the religious houses appear to have suffered no other appreciable loss," at p. 419). See also, Golding, "An Introduction to the Hampshire Domesday," pp. 11-13.

9o Acta, nos. 1-3 (Abbotsbury), 4-5 (Abingdon), 11-12 (Bath), 151 (Glastonbury), nos. 193, 195 (Malmesbury), nos. 337-41 (Old Minster, Winchester). For the settlement of disputes, Bates, William the Conqueror, pp. 442-43.

91 Annales monasterii de Wintonia, in Annales Monastici, ed. Henry R. Luard, RS 36, 5 vols (London, 1864-69), 2:1-125, at pp. 34-35; John T. Appleby, "Richard of Devizes and the Annals of Winchester," Bulletin of the Institute of Historical Research 36 (1963), 70-77, at 73.

92 For these cases, Bates, "Guillaume le Conquérant et les abbés anglais," pp. 336, 338, with references given there.

93 GDB, fol. $87 \mathrm{v}$.

94 GDB, fol. 43r. For Bury St Edmunds, GDB, fol. 222r; 2, fol. 21or. 
and, in the case of Glastonbury, the wealthiest of all the monasteries, there is evidence of the removal of estates on an extensive scale. ${ }^{95}$

As already indicated by the take-over of the New Minster's cemetery for the royal palace, William was certainly prepared to divert Church property to his own uses. However, as in the case of Windsor and the abbey of Westminster mentioned above, the transaction had involved an exchange; it is even possible that the Domesday jurors' comment that the exchange was an unjust one indicates that William had not needed to be so generous. ${ }^{96}$ William had also handed out three hides of Old Minster land in Wiltshire to William Escudet on a life-tenure. ${ }^{97}$ Any assessment of his activities is, however, complicated by later evidence, one aspect of which is a series of charters that William's grandson Bishop Henry of Winchester obtained from his recently crowned brother King Stephen that purport to list estates that William had taken from the Old Minster. ${ }^{98}$ New Minster also claimed in a 12th-century forged charter that William had inflicted extensive damage on the monastery. ${ }^{99}$

In the absence of the comprehensive modern history of Winchester's religious institutions in the period from the 1oth to the 12th century that needs to be written, it is enough to say for now that in every case, the history of many of the estates that Bishop Henry's charters claim turns out to be complicated. ${ }^{100}$ Thus, Hayling Island had been granted by William to the abbey of Jumièges in 1067 and is duly entered as being held by the abbey in Domesday Book. However, Domesday also says that the monks of the Old Minster claim it on the basis of a grant by Queen Emma and that it had been held in 1066 by Queen Edith. Along with other evidence, it also shows that the monks had granted it out on a lease. ${ }^{101}$ The cases of East Meon (Hants) and Wargrave (Berkshire)

95 For Glastonbury's losses, Lesley Abrams, Anglo-Saxon Glastonbury: Church and Endowment (Woodbridge, 1996), pp. 272-317; Charters of Glastonbury Abbey, ed. Susan E. Kelly, Anglo-Saxon Charters 15 (Oxford, 2012), pp. 74-76, and 132-38 (N.B. "13\% of the estates to which the abbey had some kind of claim were lost after the Conquest," p.76).

96 Acta, no. 344; G DB, fol.43r.

97 English Episcopal Acta, 8: Winchester 1070-1204, ed. M.J. Franklin (Oxford, 1993), no.18.

98 Regesta Regum Anglo-Normannorum: vol. III, Regesta Regis Stephani ac Mathildis Imperatricis ac Gaufridi et Henrici Ducum Normannorum, 1135-1154, ed. H.A. Cronne and R.H.C. Davis (Oxford, 1968), nos. 945-51.

99 Alexander R. Rumble, Property and Piety in Early Medieval Winchester (Oxford, 2002), $178-79$.

100 For a similar observation, The Liber Vitae of the New Minster and Hyde Abbey, Winchester, ed. Simon Keynes, Early English Manuscripts in Facsimile 26 (Copenhagen 1996), p. 42, n. 243. For the crucial Codex Wintoniensis, see for now, Alexander R. Rumble, "The Purposes of the Codex Wintoniensis," ANS 4 (1982), 153-66 and 224-32, at pp. 158-60.

101 Acta, no. 159; G DB, fol. 43v; Anglo-Saxon Charters, ed. A.J. Robertson, 2nd. ed. (Cambridge, 1956), no.114, p. 212 (S 1476). 
were also complicated, with the monks of Old Minster forging a charter of Edward the Confessor in the 12th century that claimed it had been given by Queen Emma. ${ }^{102}$ Crowcombe (Somerset) is, however, apparently straightforward since Domesday lists it as an Old Minster estate in 1066 that was held in 1086 by Count Robert of Mortain. ${ }^{103}$ This and the apparently contrasting experiences of Glastonbury and the religious houses closer to Winchester suggest that we must make a distinction between a Wessex heartland around Winchester where there was no dominant secular power other than the king and his sheriff and the more peripheral Somerset where Glastonbury's main predators, Bishop Geoffrey of Coutances and Count Robert of Mortain, held massive lands and dominated local society. William arguably showed a greater respect for English religious institutions than some of his closest associates. It is also the case that bishops and abbots appointed by William at Winchester and Abingdon could be disrespectful to the great English saints despite William's own emphasis on a legitimacy derived from the past; we are dealing once more with the complexities that followed from newcomers trying to work in what they thought to be circumstances so unfamiliar that change was needed..$^{104}$

\section{Conclusion}

Ultimately the history of William the Conqueror and Wessex does conform to William of Poitiers' comment that Winchester, which he called "a noble and strong town," was a suitable place from which to rule England. If William, who was William the Conqueror's chaplain, is here conveying the king's thoughts, then we have a valuable insight into the king's intentions. ${ }^{105}$ That the huge new cathedral at Winchester must surely reflect William's personal opinions is another sign of this. Arguably the history also fits well with the famous verdict of the anonymous English author of the homiletic obituary in the 'E' version of the Anglo-Saxon Chronicle, with its mentions of grandeur, greed, the imposition of excessive rents, an excessive devotion to hunting, and the protection of

\footnotetext{
102 As noted above, East Meon is recorded in Domesday as held by Archbishop Stigand for the monks, making a confusion between his extensive personal estates and monastic lands plausible. For Wargrave, Anglo-Saxon Charters, ed. Robertson, no. 118 (S 1062); F.E. Harmer, "Anglo-Saxon Charters and the Historian," Bulletin of the John Rylands Library 22 (1938), 339-67, at pp. 349-51.

103 GDB, fol. 91v.

104 Rebecca Browett, "The Fate of Anglo-Saxon Saints after the Norman Conquest of England: St Æthelwold of Winchester as a Case Study," History 101 (2016), 183-200.

105 WP, II.35, pp. 164-65 (Guenta urbs est nobilis et ualens).
} 
monasteries. ${ }^{106}$ In its way it epitomises the eternal conundrum of the positives and negatives of England's history in the aftermath of 1066 and of William's life that perplex all who try to write about him. It has to be a telling commentary on the arguably dazzling effect on memory of William's exercise of power in Wessex that his grandsons King Stephen and Bishop Henry of Winchester were prepared publicly to endorse the belief that he had unjustly removed estates from the Church that does not seem to be justified by the 11th-century evidence.

One can wonder what would have occurred if the 1oth-century English kings had located their power-base in Mercia; the cross-Channel empire and Wessex's role within it certainly would not have evolved as they did and the practical exercise of cross-Channel rule could even have been seriously compromised. It must also be noted that the massive expansion of the royal lands in Wessex that took place was actually a product of Harold's accession to kingship. If he had won the Battle of Hastings, he might well have placed an enhanced emphasis on Wessex's centrality to English kingship. While the second half of the 12th century is justifiably written about in terms of Winchester's decline, it is arguably doubtful that William would have wanted this to happen. ${ }^{107}$ In the end the work of this volume's honorand is the indispensable basis for all serious analysis of a long-term continuum in which William the Conqueror's reign was a significant episode.

\section{Postscript}

Since this article was passed over to the editors for publication, the remarkable Chew Valley coin hoard has been discovered. Found by metal detectorists in January 2019, it has yet to be analysed in depth. Gareth Williams of the British Museum has nonetheless made available to me a preliminary survey to indicate how its contents are likely to affect knowledge of William the Conqueror and Wessex. Containing 2,528 coins and comprising nearly twice as many of King Harold's coins and almost five times as many of William the Conqueror's first issue than were hitherto known, it is going to make a huge difference to numismatic analysis and its implications for the history of this turbulent period.

$106 \quad A S C \mathrm{E} 1086$.

107 Kenji Yoshitake, "The Place of Government in Transition: Winchester, Westminster and London in the Mid-Twelfth Century," in Rulership and Rebellion in the Anglo-Norman World, c.1066-c.1216: Essays in Honour of Professor Edmund King, Paul Dalton and David Luscombe (Farnham, 2015), pp. 61-75. 
Its contents must date from 1067-69. The hoard's very existence suggests, as my chapter does, that conditions in Wessex were more unsettled than is often thought. The presence of coins of William's first issue from almost all of the south-western and Wessex mints nonetheless indicates that the new regime was able to organise minting throughout the region from the very beginning. But the presence of over 100 Harold coins from the Wilton mint suggests that minting of Harold coins continued there, probably under the auspices of his sister Queen Edith up until the time that she came to terms with William. We will learn much more when a detailed catalogue and analysis are published. 